\title{
Decision Support System Determination of Main Work Unit in WPP-711 using Fuzzy TOPSIS
}

\author{
Hozairi $^{\text {a, } 1, *}$, Yaser Krisnafi ${ }^{\text {b, } 2}$ \\ a Informatics Eng. Study Program, Universitas Islam Madura, Jl. PP Miftahul Ulum Bettet, Pamekasan 69317, Indonesia \\ ${ }^{b}$ Fishing Technology Study Prog., Sekolah Tinggi Perikanan, Jl. AUP No. 1 Pasar Minggu, Jakarta 12520, Indonesia \\ ${ }^{1}$ dr.hozairi@gmail.com*,2yaser_bunda@yahoo.co.id \\ * corresponding author
}

Article history:

Received 27 August 2017

Revised 15 September 2017

Accepted 20 October 2017

Published online 8 January 2018

\section{Keywords:}

Decision support system

Fuzzy TOPSIS

Working unit

WPP-711
Decision-making to determine the working units for being prioritized to be developed in order to improve fishery monitoring in WPP-711 is imperative. The Ministry of Maritime Affairs and Fisheries should make no mismatch decision-making through long-term calculation and analysis. The problem of determining the priority of working units is a complex problem, thus it is required to find an appropriate method to avoid a mismatch decision. Technique for Order of Preference by Similarity to Ideal Solution (TOPSIS) is a decision-making method capable of solving multi-criteria problems. TOPSIS working principle determines the alternative by considering the shortest distance from the positive ideal alternative and furthest from the ideal negative solution. To improve the performance of TOPSIS, this research is integrated with Fuzzy logic with the aim of giving the right numeric value preference. From the test of 11 alternatives of 6 criteria, the priority of development of fishery monitoring in FMA 711 is: Pontianak Working Unit $=0.883$, Batam Working Unit $=0.767$ Natuna Working Unit $=0.681$ and Tanjung Pinang Working Unit $=0.423$. Furthermore, the ranking result will be used as the basis for determining the strategy in increasing the monitoring of WPP-711 to minimize State losses due to the illegal fishing within Indonesia's WPP-711 Regions.

This is an open access article under the CC BY-SA license (https://creativecommons.org/licenses/by-sa/4.0/).

\section{Introduction}

The marine and fishery sector has a strategic role in supporting the development of the national economy. Indonesia has the potential for major fisheries resources, where in fact the production reaches \pm 6.26 million tons per year. As a result, Indonesia became a target of illegal fishing by fishermen from several neighboring countries.

Republic of Indonesia Legislation No. 27 of 2007 mandates on the management of coastal areas and small islands which belongs to the legitimacy of fishery resources control activities. Surveillance and law enforcement in the field of fisheries is one of the main tasks and functions for the Directorate of Fishery patrol boat which is implemented through a patrol boat in conducting a surveillance operation of marine resources and fisheries. In accordance with the main duties and functions of the fishery patrol boat in Table 1, the area of operation of the fishery patrol boat is divided into 2 (two): West Region (Strait of Malacca, South China Sea, the Indian Ocean, Mentawai of western Sumatra to the south of Java), and Eastern Region (Ocean Indian, northeast Flores, Banda Sea, Arafura Sea, the Maluku Sea, Gulf of Tomini, Sulawesi Sea And Pacific oceans).

Fisheries Management Areas are the Republic of Indonesia or often referred as WPP NRI in Indonesian (or WPP in English) is a fishery management area for fishing, conservation, research, and development of fisheries covering the waters, the archipelagic waters, territorial sea, contiguous zone and exclusive economic zone of Indonesia (EEZ). Pursuant to the Regulation of the Minister of Marine and Fisheries No.01 / MEN / 2009 on Regional Fisheries Management of the Republic of Indonesia, it has set the division into 11 WPP (Indonesia, 2014), in detail WPP division is illustrated in Fig. 1 
Table 1. Fishery patrol boats.

\begin{tabular}{lllll}
\hline No & Type & Amount & Size $(\mathbf{m})$ & Material \\
\hline 1 & FPB Hiu Macan Tutul & 2 & 42 & Iron + Alumunium \\
2 & FPB Hiu Macan & 6 & 36 & Iron + Alumunium, Fiberglass \\
3 & FPB Hiu & 15 & 27 & Alumunium, Fiberglass \\
4 & FPB Takalamongan & 1 & 21 & Fiberglass \\
5 & FPB Padaido & 1 & 21 & Fiberglass \\
6 & FPB Todak & 2 & 17 & Fiberglass \\
7 & FPB Baracuda & 2 & 17 & Fiberglass \\
8 & FPB Paus & 1 & 36 & Baja \\
9 & FPB Akar Bahar & 1 & 15 & Fiberglass \\
10 & FPB Orca & 4 & 60 & Iron + Alumunium \\
\hline
\end{tabular}

Source: Processed Primary Data

According to the data from the Ministry of Marine Affairs and Fisheries (KKP) in 2015, there are 3 (three) areas in Indonesian waters with high vulnerability to the illegal fishing by foreign fishing vessels as Table 2 presented. From the three prone areas, one region is included in WPP-711, it is Natuna Sea. Based on Table 2, it is explained that the highly vulnerable water areas are present in WPP-711 covering several work units spreading in the region. This study aims at determining the priority of work unit area in FMA 711 with 11 (eleven) alternatives and 6 (Six) criteria, so as to be able to find the work unit area which is very potential to improve the supervision of wild fisheries. Criteria and alternative names can be seen in Tables 3 and 4 . Working unit area priority determination is considered as discrete issues. It aims at designating the outstanding alternative from a number of alternatives provided in accordance with several existing particular criteria which at the end of the problems could be immediately resolved using Multi Criteria Decision Making (MCDM) method [1], [2].

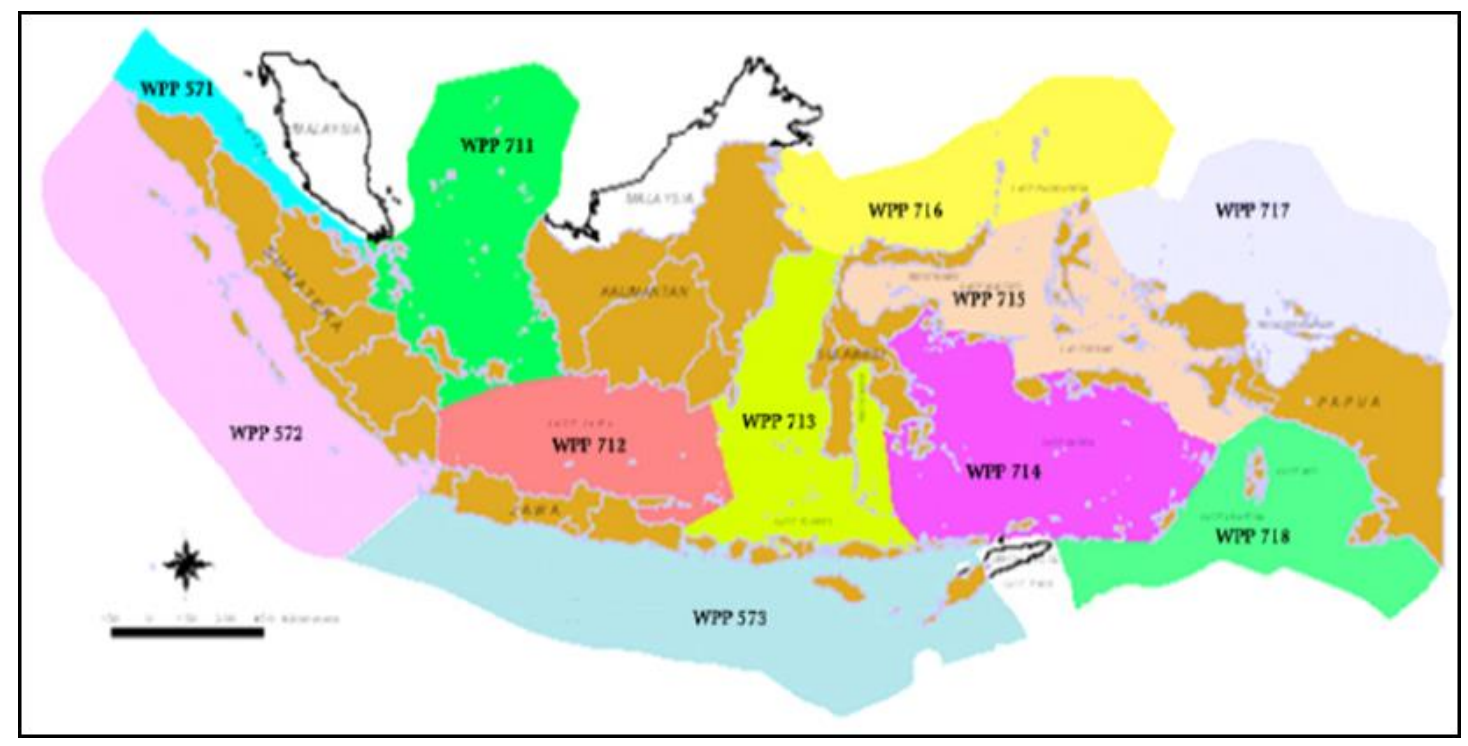

Fig. 1. Indonesian fishery management areas map

Table 2. Indonesia's areas prone to illegal fishing

\begin{tabular}{lll}
\hline Area1 & Area2 & Area3 \\
\hline Natuna Sea & Sulawesi Sea & Arafura Sea \\
Chinese Fishermen & Philippine Fishermen & Chinese Fishermen \\
Vietnamese Fishermen & Malaysian Fishermen & Thai Fishermen \\
Thai Fishermen & & \\
\hline
\end{tabular}


Table 3. Working unit determination priority criteria

\begin{tabular}{ll}
\hline Code & Criteria \\
\hline K1 & Border Area \\
K2 & Potential Fish Resources \\
K3 & International Sea Lanes \\
K4 & Infrastructure \\
K5 & Patrol Ship Amount \\
K6 & Law Enforcement \\
\hline
\end{tabular}

Table 4. Working unit WPP 711 alternative

\begin{tabular}{ll}
\hline Code & Working Unit WPP-711 \\
\hline A1 & SDKP Pontianak \\
A2 & Pemangkat \\
A3 & Teluk Batang \\
A4 & Sungai Liat \\
A5 & Tanjung Balai Karimun \\
A6 & Moro \\
A7 & Batam \\
A8 & Tarempa \\
A9 & Natuna \\
A10 & Pulau Kijang \\
A11 & Tanjung Pinang \\
\hline
\end{tabular}

The method developed to determine working unit priorities in WPP-711 is a Technique for Order of Preference by Similarity to Ideal Solution (TOPSIS). This method work by employing the principle that the alternative chosen should have the shortest distance from the ideal positive solution and farthest from the negative ideal solution by using Euclidean distance to determine the relative proximity of an alternative to the optimal solution [3], [4]. TOPSIS considers both, the distance of positive ideal solution and the distance of negative ideal solution by taking the proximity relative to the positive ideal solution. Based on a comparison of the relative distance, an alternative set of priorities can be achieved [5], [6].

The main advantage of TOPSIS compared with other MCDM methods in complex problem decision making is simple to use, can take into account all kinds of criteria (subjective and objective), Rational logic and easy to understand for practitioners, the calculation of the process is very easy, the concept allows the pursuit of the best alternative criteria depicted in mathematics simply and important weight can be incorporated easily [2], [7], [8], [9]. In TOPSIS, performance rating and the weight of these criteria are given as crisp values. One of the problems of traditional TOPSIS is the use of crisp values in the evaluation process. Another difficulty to use crisp values is that some criteria are difficult to measure by crisp values, so during evaluation these criteria are usually ignored [10], [11]. Using triangle fuzzy for fuzzy TOPSIS to simplify the process of calculating fuzzy triangle numbers in the decision making process. In addition, it has been verified that modeling with triangular fuzzy numbers is an effective way of formulating decision problems with available information being subjective and inaccurate [12], [13], [14].

\section{Methods}

This research was initiated from distributing questionnaires to 25 respondents (expert) who is acquainted and understand the condition of WPP-711. The purpose of this questionnaire as input data to test the consistency of the assessment of each alternative. The rating assessment are Very Bad (VB), Bad (B), Average (A), Good (G), and Very Good (VG).

If it is converted to crisp, the value aggregation of the questionnaire uses five fuzzy numbers as shown in Fig. 2: The results of the questionnaire assessment based on the predetermined rating can be 
seen in Table 5 on Alternative A1 (Pontianak Work Unit). The next step is to convert it into fuzzy numbers according to the fuzzy set in Table 6 , obtained the following results:

- $\mathrm{K} 1=5=(0.75,1,1)$

- $\mathrm{K} 2=5=(0.75,1,1)$

- $\mathrm{K} 3=4=(0.5,0.75,1)$

- $\mathrm{K} 4=4=(0.5,0.75,1)$

- $\mathrm{K} 5=4=(0.5,0.75,1)$

- $\mathrm{K} 6=4=(0.5,0.75,1)$

Furthermore, to form a decision matrix of fuzzy number results, then the next step is the defuzification process that is every alternative in each criteria is taken the average value so that obtained the decision matrix value as in Table 7.

Afterwards, following TOPSIS stage must be completed.

1. Create a normalized and weighted decision matrix.

2. Determine the matrix of positive and negative ideal solutions.

3. Determine the distance between the value of each alternative with the ideal positive solution matrix and the ideal negative solution matrix.

4. Specifies the preference value for each alternative.

5. Determine the ranking.

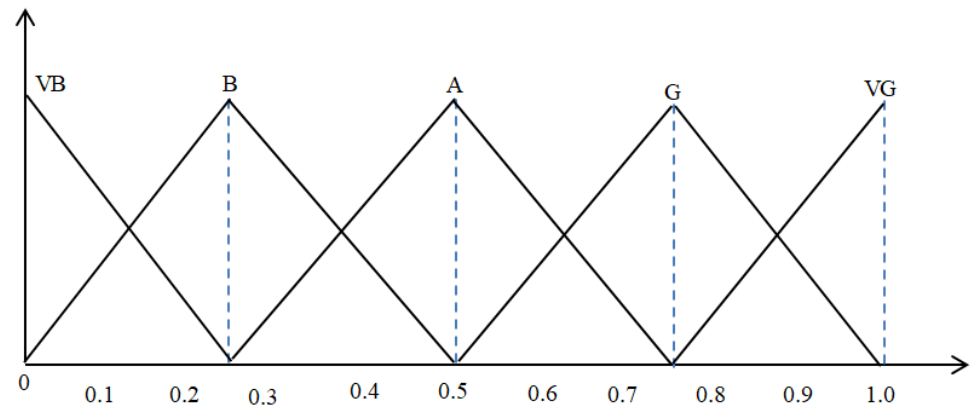

Fig. 2. Membership function

Table 5. Questionnaire recapitulation result

\begin{tabular}{lllllll}
\hline Alternative & K1 & K2 & K3 & K4 & K5 & K6 \\
\hline A1 & 5 & 5 & 4 & 4 & 4 & 4 \\
A2 & 4 & 2 & 4 & 3 & 3 & 1 \\
A3 & 3 & 1 & 4 & 1 & 2 & 1 \\
A4 & 3 & 2 & 3 & 4 & 2 & 1 \\
A5 & 4 & 4 & 3 & 1 & 2 & 1 \\
A6 & 5 & 1 & 3 & 3 & 2 & 1 \\
A7 & 5 & 4 & 4 & 3 & 3 & 3 \\
A8 & 4 & 3 & 4 & 2 & 2 & 1 \\
A9 & 4 & 5 & 5 & 4 & 3 & 3 \\
A10 & 5 & 3 & 3 & 2 & 2 & 1 \\
A11 & 5 & 2 & 3 & & 2 & 3 \\
\hline
\end{tabular}

Source: Survey Result

Table 6. Square and root value results

\begin{tabular}{lllllll}
\hline Value & K1 & K2 & K3 & K4 & K5 & K6 \\
\hline Square & 6.951 & 3.507 & 4.903 & 2.826 & 1.750 & 1.361 \\
Root & 2.637 & 1.873 & 2.214 & 1.681 & 1.323 & 1.167 \\
\hline
\end{tabular}


Decision matrix with 11 alternatives and 6 criteria such as in Table 7.

$$
D=\left[\begin{array}{ccc}
X_{11} & . . & X_{1 n} \\
\ldots & . . & \ldots \\
X_{m 1} & . . & X_{m n}
\end{array}\right]
$$

where $\mathrm{D}$ is matrix, $\mathrm{m}$ is alternative, $\mathrm{n}$ is criteria, $\mathrm{Xij}$ is $\mathrm{i}$-th alternative and $\mathrm{j}$-th Criteria.

The following steps and formulas are aimed at resolving problems using TOPSIS method:

\section{A. Normalization of Decision Matrix}

Each element in the matrix D is normalized to obtain normalization matrix $r$. Each normalization of the $r$ value can be calculated for $i=1,2,3, \ldots \ldots, m$, and $j=1,2,3, \ldots ., n$. The results of the squared and root values in the decision matrix can be seen in Table 8 .

$$
r_{i j}=\frac{X_{i j}}{\sqrt{\sum_{i=1}^{m} X_{i j}^{2}}}
$$

\section{B. Normalized Weighting Matrix}

Assigned weights $\mathrm{W}=(\mathrm{w} 1, \mathrm{w} 2, \ldots, \mathrm{wn})$, hence Weighted Normalized matrix $\mathrm{V}$ is generated with $\mathrm{i}=1,2,3, \ldots . \mathrm{m}$ and $\mathrm{j}=1,2,3, \ldots ., \mathrm{n}$. The result of the normalized matrix is presented in Table 9 and 10 .

$$
\left[\begin{array}{ccc}
W_{11} r_{11} & \ldots & W_{1 n} r_{1 n} \\
\ldots \ldots \ldots . & \ldots & \ldots \ldots \ldots . \\
W_{m 1} r_{m 1} & \ldots & W_{n m} r_{n m}
\end{array}\right]
$$

Table 7. Normalized matrix results

\begin{tabular}{lllllll}
\hline Value & K1 & K2 & K3 & K4 & K5 & K6 \\
\hline A1 & 0.348 & 0.489 & 0.339 & 0.446 & 0.567 & 0.643 \\
A2 & 0.284 & 0.133 & 0.339 & 0.297 & 0.378 & 0.071 \\
A3 & 0.190 & 0.044 & 0.339 & 0.050 & 0.189 & 0.071 \\
A4 & 0.190 & 0.133 & 0.226 & 0.446 & 0.189 & 0.071 \\
A5 & 0.284 & 0.400 & 0.226 & 0.050 & 0.189 & 0.071 \\
A6 & 0.348 & 0.044 & 0.226 & 0.297 & 0.189 & 0.071 \\
A7 & 0.348 & 0.400 & 0.339 & 0.297 & 0.378 & 0.429 \\
A8 & 0.284 & 0.267 & 0.339 & 0.149 & 0.189 & 0.071 \\
A9 & 0.284 & 0.489 & 0.414 & 0.446 & 0.378 & 0.429 \\
A10 & 0.348 & 0.267 & 0.226 & 0.149 & 0.189 & 0.071 \\
A11 & 0.348 & 0.133 & 0.226 & 0.297 & 0.189 & 0.429 \\
\hline
\end{tabular}

Table 8. Normalized weighting matrix results

\begin{tabular}{lllllll}
\hline Value & K1 & K2 & K3 & K4 & K5 & K6 \\
\hline A1 & 0.271 & 0.234 & 0.221 & 0.199 & 0.206 & 0.166 \\
A2 & 0.222 & 0.064 & 0.221 & 0.133 & 0.137 & 0.018 \\
A3 & 0.148 & 0.021 & 0.221 & 0.022 & 0.069 & 0.018 \\
A4 & 0.148 & 0.064 & 0.147 & 0.199 & 0.069 & 0.018 \\
A5 & 0.222 & 0.191 & 0.147 & 0.022 & 0.069 & 0.018 \\
A6 & 0.271 & 0.021 & 0.147 & 0.133 & 0.069 & 0.018 \\
A7 & 0.271 & 0.191 & 0.221 & 0.133 & 0.137 & 0.110 \\
A8 & 0.222 & 0.127 & 0.221 & 0.066 & 0.069 & 0.018 \\
A9 & 0.222 & 0.234 & 0.270 & 0.199 & 0.137 & 0.110 \\
A10 & 0.271 & 0.127 & 0.147 & 0.066 & 0.069 & 0.018 \\
A11 & 0.271 & 0.064 & 0.147 & 0.133 & 0.069 & 0.110
\end{tabular}


Table 9. Maximum and minimum value on each criterion

\begin{tabular}{lllllll}
\hline Value & K1 & K2 & K3 & K4 & K5 & K6 \\
\hline Maximum & 0.271 & 0.234 & 0.270 & 0.199 & 0.206 & 0.166 \\
Minimum & 0.148 & 0.021 & 0.147 & 0.022 & 0.069 & 0.018 \\
\hline
\end{tabular}

Table 10. Square value on each alternative

\begin{tabular}{lll}
\hline Value & Benefit & Cost \\
\hline Square -1 & 0.002 & 0.138 \\
Square - & 0.065 & 0.030 \\
Square -3 & 0.135 & 0.005 \\
Square - 4 & 0.100 & 0.033 \\
Square - 5 & 0.091 & 0.034 \\
Square - 6 & 0.105 & 0.027 \\
Square - 7 & 0.016 & 0.075 \\
Square - 8 & 0.074 & 0.024 \\
Square - 9 & 0.010 & 0.110 \\
Square - 10 & 0.085 & 0.028 \\
Square - 11 & 0.070 & 0.038 \\
\hline
\end{tabular}

\section{Determining Positive Ideal Solutions and Negative Ideal Solutions}

The positive ideal solution is denoted by $\mathrm{A}+$ and the negative ideal solution is denoted by ADefine the ideal solution (+) \& (-).

$$
\begin{aligned}
& A^{+}=\left\{\left(\max v_{i j} \mid j \in J\right)\left(\min v_{i j} \mid j \in J\right), i=1,2,3, \ldots, m\right\}=\left\{v_{1}^{+}, v_{2}^{+}, v_{3}^{+}\right\} \\
& A^{-}=\left\{\left(\max v_{i j} \mid j \in J\right)\left(\min v_{i j} \mid j \in J\right), i=1,2,3, \ldots, m\right\}=\left\{v_{1}^{-}, v_{2}^{-}, v_{3}^{-}\right\}
\end{aligned}
$$

where:

$\mathrm{Vij}=\mathrm{V}$ matrix element $\mathrm{i}$-th row and $\mathrm{j}$-th column

$J=\{j=1,2,3, \ldots, n$ and $j$ due to benefit criteria)

$\mathrm{J}^{\prime}=\{\mathrm{j}=1,2,3, \ldots, \mathrm{n}$ and $\mathrm{j}$ in connection with the cost criteria)

\section{Separation Measure Counting}

Separation measure is a measurement of the distance from an ideal alternative solution to the positive and negative ideal solution. The mathematical calculations are:

- Separation measure for positive ideal solution with $\mathrm{i}=1,2,3, \ldots, \mathrm{n}$

$$
S_{i}^{+}=\sqrt{\sum_{j=1}^{n}\left(V_{i j}-V_{j}^{+}\right)^{2}}
$$

- Separation measure for negative ideal solution with $\mathrm{i}=1,2,3, \ldots, \mathrm{n}$

$$
S_{i}^{-}=\sqrt{\sum_{j=1}^{n}\left(V_{i j}-V_{j}^{-}\right)^{2}}
$$

The result of separation measure is presented in Table 12 and 13.

\section{E. Calculating Proximity Relative to Positive Ideal}

The relative proximity of an A + alternative with an ideal solution A- is represented by:

$$
C_{i}=\frac{s_{i}^{-}}{S_{i}^{-}+S_{i}^{+}}
$$


Table 11. Root value on each alternative

\begin{tabular}{lll}
\hline Value & Benefit & Cost \\
\hline Square - 1 & 0.049 & 0.371 \\
Square - 2 & 0.254 & 0.172 \\
Square - 3 & 0.367 & 0.074 \\
Square - 4 & 0.316 & 0.182 \\
Square - 5 & 0.302 & 0.185 \\
Square - 6 & 0.324 & 0.166 \\
Square - 7 & 0.128 & 0.274 \\
Square - 8 & 0.273 & 0.155 \\
Square - 9 & 0.101 & 0.332 \\
Square - 10 & 0.291 & 0.169 \\
Square - 11 & 0.265 & 0.194 \\
\hline
\end{tabular}

Table 12. Priority value on each alternative

\begin{tabular}{llllllllllll}
\hline Satker & A1 & A2 & A3 & A4 & A5 & A6 & A7 & A8 & A9 & A10 & A11 \\
\hline Priority Value & 0.883 & 0.404 & 0.167 & 0.366 & 0.380 & 0.338 & 0.681 & 0.363 & 0.767 & 0.367 & 0.423 \\
\hline
\end{tabular}

Table 13. Alternative ranking results

\begin{tabular}{llllllllllll}
\hline Code & A1 & A7 & A9 & A11 & A10 & A6 & A2 & A8 & A5 & A4 & A3 \\
\hline Priority Value & 0.883 & 0.767 & 0.681 & 0.423 & 0.404 & 0.380 & 0.367 & 0.366 & 0.363 & 0.338 & 0.167 \\
\hline
\end{tabular}

\section{F. Sorting options}

Alternatives can be ranked based on the order of $\mathrm{Ci}$, therefore, the best alternative is the one that is the shortest of the ideal solution and is the furthest to the negative ideal solution.

\section{Results and Discussion}

Table 7 presents the result of the questionnaire assessment for each criterion in each alternative with predetermined criteria. Below is an instance of an assessment on alternative Pontianak Working Unit $=[0.92,0.92,0.75,0.75,0.75,0.75]$, meaning:
1. Border Area [K1]
$=0.92$ [Very Good].
2. Potential Fish resources [K2]
$=0.92[$ Very Good $]$
3. International Sea Lanes [K3]
$=0.75[\mathrm{Good}]$
4. Infrastructure [K4]
$=0.75$ [Good]
5. Patrol Ship Amount [K5]
$=0.75$ [Good]
6. Law Enforcement [K6]
$=0.75[\mathrm{Good}]$

After weighting the preference of each criterion on each alternative, the next phase is to find the value of squares and roots of each criterion as shown in Table 8. Below is one of the calculation process of the value of squares and roots on the criteria of the border area [K1].

$$
\begin{aligned}
|\mathrm{K} 1|= & {[\mathrm{A} 1] 2+[\mathrm{A} 2] 2+[\mathrm{A} 3] 2+[\mathrm{A} 4] 2+[\mathrm{A} 5] 2+[\mathrm{A} 6] 2+[\mathrm{A} 7] 2+[\mathrm{A} 8] 2+[\mathrm{A} 9] 2+[\mathrm{A} 10] 2+} \\
& {[\mathrm{A} 11] 2 . } \\
|\mathrm{K} 1|= & {[0.92] 2+[0.75] 2+[0.50] 2+[0.50] 2+[0.75] 2+[0.92] 2+[0.92] 2+[0.75] 2+[0.75] 2+} \\
& {[0.92] 2+[0.92] 2 . } \\
|\mathrm{K} 1|= & 6.951 \text { (square value) } \\
|\mathrm{K} 1|= & \sqrt{ } 6.951=2.637 \text { (root value) }
\end{aligned}
$$


Using the similar approach will obtain root value from several criteria as follows:

$$
\begin{aligned}
& \mathrm{K} 2=\sqrt{ } 3.507=1.873 \\
& \mathrm{~K} 3=\sqrt{ } 4.903=2.214 \\
& \mathrm{~K} 4=\sqrt{ } 2.826=1.681 \\
& \mathrm{~K} 5=\sqrt{ } 1.750=1.323 \\
& \mathrm{~K} 6=\sqrt{ } 1.174=1.083
\end{aligned}
$$

\begin{tabular}{|c|c|c|}
\hline R11 & $=\mathrm{X} 11 / \mathrm{K} 1$ & $=0.92 / 2.637=0,348$ \\
\hline R21 & $=\mathrm{X} 21 / \mathrm{K} 1$ & $=0.75 / 2.637=0,284$ \\
\hline R31 & $=\mathrm{X} 31 / \mathrm{K} 1$ & $=0.50 / 2 \cdot 637=0,190$ \\
\hline R41 & $=\mathrm{X} 41 / \mathrm{K} 1$ & $=0.50 / 2 \cdot 637=0,190$ \\
\hline R51 & $=\mathrm{X} 51 / \mathrm{K} 1$ & $=0.75 / 2.637=0,284$ \\
\hline R61 & $=\mathrm{X} 61 / \mathrm{K} 1$ & $=0.92 / 2.637=0,348$ \\
\hline R71 & $=\mathrm{X} 71 / \mathrm{K} 1$ & $=0.92 / 2.637=0,348$ \\
\hline R81 & $=\mathrm{X} 81 / \mathrm{K} 1$ & $=0.75 / 2.637=0,284$ \\
\hline R91 & $=\mathrm{X} 91 / \mathrm{K} 1$ & $=0.75 / 2.637=0,284$ \\
\hline R101 & $=\mathrm{X} 101 / \mathrm{K} 1$ & $=0.92 / 2.637=0,348$ \\
\hline 111 & $=\mathrm{X} 111 / \mathrm{K} 1$ & $=0.92 / 2.637=0,348$ \\
\hline
\end{tabular}

After obtaining the value of squares and root values on each criterion such as in Table 8, the next process is calculating the normalization matrix of border areas (K1) in each alternative as in Table 9.

Having obtained the normalized matrix value, the next step is to determine the weighted normalization matrix. Before calculating the weighted normalization decision matrix, it firstly determines the weight of each criterion. The importance of each criterion can be assessed from range 1 to 5, namely:

1. Not at all important

2. Slightly important

3. Fairly important

4. Important

5. Very important

The value of the initial weight (W) is used to indicate the relative importance of each criterion. The weights of each criterion are listed in Table 7. After determining the weight of each criterion, then based on the first step and equation 2, the weighted normalization matrix as in table 8 can be calculated. The following instances are a weighted matrix calculation.

$\begin{array}{lll}\mathrm{Y} 11 & =\mathrm{W} 11 * \mathrm{R} 11 & =0.348 * 0.78=0.917 \\ \mathrm{Y} 21 & =\mathrm{W} 11 * \mathrm{R} 21 & =0.284 * 0.78=0.750 \\ \mathrm{Y} 31 & =\mathrm{W} 11 * \mathrm{R} 31 & =0.190 * 0.78=0.500 \\ \mathrm{Y} 41 & =\mathrm{W} 11 * \mathrm{R} 41 & =0.190 * 0.78=0.500 \\ \mathrm{Y} 51 & =\mathrm{W} 11 * \mathrm{R} 51 & =0.284 * 0.78=0.750 \\ \mathrm{Y} 61 & =\mathrm{W} 11 * \mathrm{R} 61 & =0.348 * 0.78=0.917 \\ \mathrm{Y} 71 & =\mathrm{W} 11 * \mathrm{R} 71 & =0.348 * 0.78=0.917 \\ \mathrm{Y} 81 & =\mathrm{W} 11 * \mathrm{R} 81 & =0.284 * 0.78=0.750 \\ \mathrm{Y} 91 & =\mathrm{W} 11 * \mathrm{R} 91 & =0.284 * 0.78=0.750 \\ \mathrm{Y} 101 & =\mathrm{W} 11 * \mathrm{R} 101 & =0.348 * 0.78=0.917\end{array}$


$\mathrm{Y} 111=\mathrm{W} 11 * \mathrm{R} 111=0.348 * 0.78=0.917$

The next step is to determine the ideal positive solution matrix and the ideal solution matrix based on equations 3 and 4.

Positive ideal solution matrix (Yij+):

$$
\begin{aligned}
& \mathrm{A}+=(\mathrm{y} 1+, \mathrm{y} 2+, \mathrm{y} 3+, \ldots \ldots, \mathrm{yn}+) ; \\
& \mathrm{A}^{-}=(\mathrm{y} 1-, \mathrm{y} 2-, \mathrm{y} 3-, \ldots \ldots ., \mathrm{yn}-) ; \\
& y_{j}^{+}=\left\{\begin{array}{l}
\max y_{i j} \\
\min y_{i j}
\end{array}\right.
\end{aligned}
$$

The positive ideal solution is calculated as follows:

$$
\begin{gathered}
y_{1}^{+}=\max (0.917,0.750, \ldots)=0.917 \\
y_{2}^{+}=\max (0.234,0.064, \ldots)=0.234
\end{gathered}
$$

And so on, hence obtained:

$$
A^{+}=(0.917,0.234,0.270,0.199,0.209,0.163)
$$

The positive ideal solution is calculated as follows:

$$
\begin{gathered}
y_{1}^{-}=\min (0.917,0.750, \ldots)=0.500 \\
y_{2}^{-}=\min (0.234,0.064, \ldots)=0.021
\end{gathered}
$$

And so on, hence obtained:

$$
A^{-}=(0.500,0.021,0.147,0.022,0.069,0.018)
$$

The final result of a positive ideal solution and a negative ideal solution is illustrated in Table 11.

The next phase is to determine the distance between the value of each alternative with a positive ideal solution matrix \& the negative ideal solution matrix. To discover the distance between alternatives with ideal positive solution matrices, the following equation is applicable:

$$
D_{i}^{+}=\sqrt{\sum_{j=1}^{n}\left(y_{i}^{+}-y_{i j}\right)^{2}}
$$

The distance between alternative A, with the negative ideal solution, is formulated as:

$$
\begin{aligned}
& D_{i}^{-}=\sqrt{\sum_{j=1}^{n}\left(y_{i j}-y_{i}^{-}\right)^{2}} \\
& \mathrm{\imath}=1,2 \ldots v
\end{aligned}
$$

The result of positive and negative ideal solution distance can be seen in Table 8 . The next phase is to determine the value of the square and the root of the positive ideal value and the negative ideal value. The results of the square values can be seen in Table 12 while the root values can be seen in Table 13. The final phase in the calculation of TOPSIS is determining preference value for each alternative given according to the following equation.

$$
V_{i}=\frac{D_{i}^{-}}{D_{i}^{-}+D_{i}^{+}}
$$

The greater $\mathrm{V}_{\mathrm{i}}$ values indicate that Ai alternatives are preferred.

\section{G. Calculating preference value}

Several preference value will be applied using certain calculation. Preference value for each working unit is described as follow.

a. Preference value of Pontianak SDKP Working Unit

$$
V_{1}=\frac{D_{1}^{-}}{D_{1}^{-}+D_{1}^{+}}=\frac{0.049}{0.547+0.049}=0.917
$$


b. Preference value of Pemangkat Working Unit

$$
V_{2}=\frac{D_{2}^{-}}{D_{2}^{-}+D_{2}^{+}}=\frac{0.298}{0.294+0.298}=0.497
$$

c. Preference value of Teluk Batang Working Unit

$$
V_{3}=\frac{D_{3}^{-}}{D_{3}^{-}+D_{3}^{+}}=\frac{0.541}{0.074+0.541}=0.120
$$

d. Preference value of Sungai Liat Working Unit

$$
V_{4}=\frac{D_{4}^{-}}{D_{4}^{-}+D_{4}^{+}}=\frac{0.507}{0.182+0.507}=0.264
$$

e. Preference value of Tanjung Balai Karimun Working Unit

$$
V_{5}=\frac{D_{5}^{-}}{D_{5}^{-}+D_{5}^{+}}=\frac{0.340}{0.302+0.340}=0.470
$$

f. Preference value of Moro Working Unit

$$
V_{6}=\frac{D_{6}^{-}}{D_{6}^{-}+D_{6}^{+}}=\frac{0.323}{0.431+0.323}=0.572
$$

g. Preference value of Batam Working Unit

$$
V_{7}=\frac{D_{7}^{-}}{D_{7}^{-}+D_{7}^{+}}=\frac{0.128}{0.483+0.128}=0.791
$$

h. Preference value of Tarempa Working Unit

$$
V_{8}=\frac{D_{8}^{-}}{D_{8}^{-}+D_{8}^{+}}=\frac{0.314}{0.314+0.285}=0.475
$$

i. Preference value of Natuna Working Unit

$$
V_{9}=\frac{D_{9}^{-}}{D_{9}^{-}+D_{9}^{+}}=\frac{0.188}{0.188+0.409}=0.685
$$

j. Preference value of Pulau Kijang Working Unit

$$
V_{10}=\frac{D_{10}^{-}}{D_{10}^{-}+D_{10}^{+}}=\frac{0.289}{0.289+0.432}=0.599
$$

k. Preference value of Tanjung Pinang Working Unit

$$
V_{11}=\frac{D_{11}^{-}}{D_{11}^{-}+D_{11}^{+}}=\frac{0.281}{0.281+0.435}=0.607
$$

The results of the preference value ranking can be recognized in Table 14 and 15. Pursuant to the preference value ranking on each working unit, four (4) working unit in WPP-711 will be prioritized to be developed, thus increasing security on WPP-711 will be optimized in the long-run.

As illustrated in Fig.3, four areas which are recommended to be developed as a central monitoring area in WPP-711 are:

1. Pontianak SDKP $=0.883$

2. Batam $=0.767$

3. Natuna $=0.681$

4. Tanjung Pinang $=0.423$

The mentioned four areas are well suited to be developed as a central monitoring area in WPP-711 considering from 6 criteria and already capable of representing some areas in WPP-711. Based on Fig. 4 , it describes the priorities of the working unit area in WPP-711. The determined working units are able to cover other areas based on the distance between regions and the level of vulnerability. The development of these four areas will be able to improve the security of Indonesia's marine resources which in the long-run minimizes the loss of the State. 


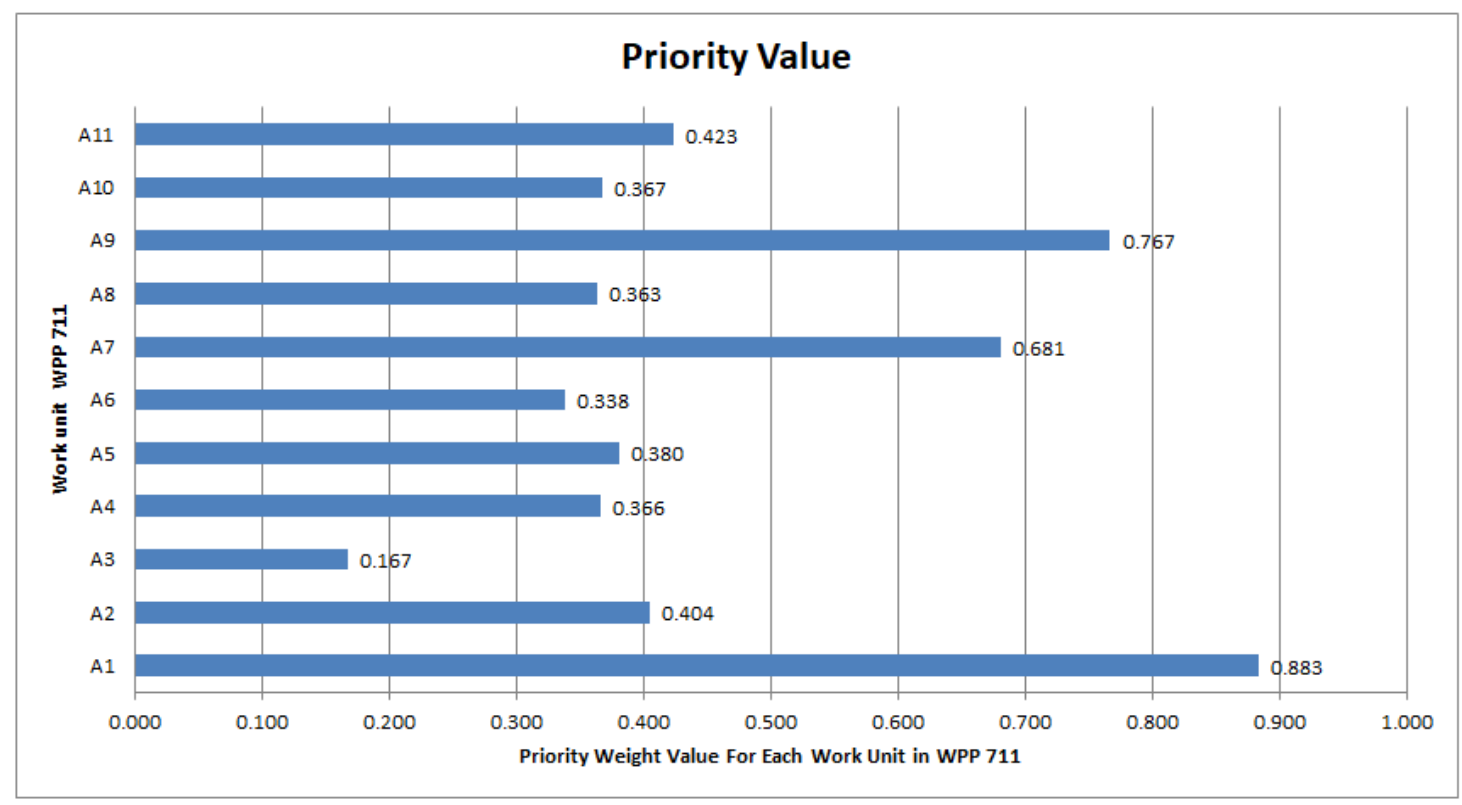

Fig. 3. Priority values of each working unit in WPP-711

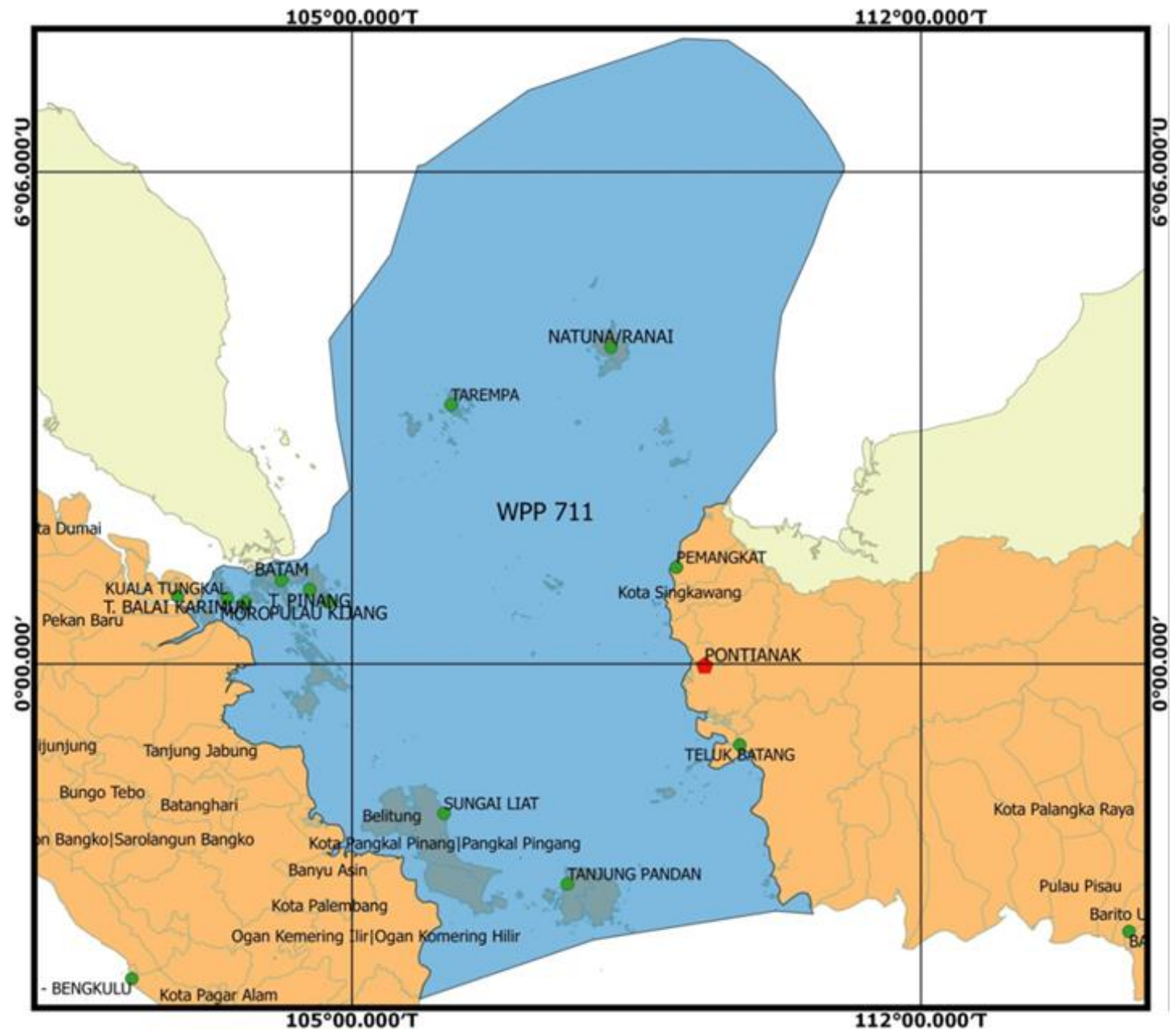

Fig. 4. Areas map according to priority values of four working units in WPP- 711 


\section{Conclusion}

This study has managed to determine 4 working units from the entire existing working units spread across WPP-711. The basic criteria are taken into consideration to improve fisheries monitoring in WPP-711 is (1) The border area, (2) the potential of fisheries resources, (3) the international sea lanes (4) facilities and infrastructures, and (5) the number of patrol ships and law enforcement. Based on the calculation of Fuzzy TOPSIS method, the result of working units priority is as follows: (1) SDKP Pontianak $=0.883$, (2) Batam $=0.767$, (3) Natuna $=0.681$ and (4) Tanjung Pinang $=0.423$. The Fuzzy TOPSIS calculation results will be taken into consideration to determine the strategy in order to improve the supervision of fishery areas in WPP 711 to reduce the loss of the State due to illegal fishing within Indonesia's legitimate region.

\section{References}

[1] A. N. Fitriana, "Decision Support System to Determine Student's Academic Achievement by TOPSIS Method," 2015, vol. 2, no. 2, pp. 153-164.

[2] C. Wang and S. Chen, "Multiple attribute decision making based on interval-valued intuitionistic fuzzy sets, linear programming methodology, and the extended TOPSIS method," Inf. Sci. (Ny)., vol. 397-398, pp. 155-167, 2017.

[3] G. Torlak, M. Sevkli, M. Sanal, and S. Zaim, "Expert Systems with Applications Analyzing business competition by using fuzzy TOPSIS method: An example of Turkish domestic airline industry," Expert Syst. Appl., vol. 38, no. 4, pp. 3396-3406, 2011.

[4] S. K. Patil and R. Kant, "Expert Systems with Applications A fuzzy AHP-TOPSIS framework for ranking the solutions of Knowledge Management adoption in Supply Chain to overcome its barriers," Expert Syst. Appl., vol. 41, no. 2, pp. 679-693, 2014.

[5] S. Abdurrahman, Book of Data and Information on Marine Resource and Fishery Monitoring. 2013.

[6] A. Hatami-marbini and F. Kangi, "An extension of fuzzy TOPSIS for a group decision making with an application to tehran stock exchange,” Appl. Soft Comput. J., vol. 52, pp. 1084-1097, 2017.

[7] E. Roszkowska and D. Kacprzak, "The fuzzy saw and fuzzy TOPSIS procedures based on ordered fuzzy numbers R, RR,” Inf. Sci. (Ny)., vol. 369, pp. 564-584, 2016.

[8] S. H. Zyoud, L. G. Kaufmann, H. Shaheen, S. Samhan, and D. Fuchs-hanusch, "A framework for water loss management in developing countries under fuzzy environment : Integration of Fuzzy AHP with Fuzzy TOPSIS," Expert Syst. Appl., vol. 61, pp. 86-105, 2016.

[9] A. Hozairi, "Selection Of Creative Industry Sector ICT Suitable Developed In Pesantren Using Fuzzy - AHP," vol. 82, no. 1, pp. 131-136, 2015.

[10] P. P. T. Samafitro, “Admission Selection Prospective Manager Using Fuzzy-TOPSIS At PT. Samafitro,” Inf. Manag. Educ. Prof., vol. 1, no. 1, pp. 86-95, 2016.

[11] F. T. Wulandari, "Fuzzy Topsis Implementation in Business Strategy Planning,” Magistra, no. 85, pp. 80-91, 2013.

[12] H. Gupta and M. K. Barua, "Supplier selection among SMEs on the basis of their green innovation ability using BWM and fuzzy TOPSIS,” J. Clean. Prod., vol. 152, pp. 242-258, 2017.

[13] P. U. Onu, X. Quan, L. Xu, J. Orji, and E. Onu, "Evaluation of sustainable acid rain control options utilizing a fuzzy TOPSIS multi-criteria decision analysis model frame work," J. Clean. Prod., vol. 141, pp. 612-625, 2017.

[14] H. Shakerian, H. D. Dehnavi, and S. B. Ghanad, "The implementation of the hybrid model SWOT-TOPSIS by fuzzy approach to evaluate and rank the human resources and business strategies in organizations ( case study : road and urban development organization in Yazd )," Procedia - Soc. Behav. Sci., vol. 230, no. May, pp. 307-316, 2016. 